Historic, archived document

Do not assume content reflects current scientific knowledge, policies, or practices. 


\section{THE AUTHORS}

GLENN H. DEITSCHMAN, a native of Minnesota, earned his B.S. degree in forestry at the University of Minnesota, and his master's degree at Penn State. His Forest Service career began at the Central States Station's branch at Carbondale, Illinois, in 1948, where he was a Research Forester in silviculture and regeneration. From 1955 to 1961 he was Research Center Leader at Ames, Iowa. Since 1961 he has been Principal Silviculturist working on research in the silviculture of western white pine at Moscow, Idaho.

ROBERT D. PFISTER, Plant Ecologist and Leader of the Forest Ecosystems research work unit at Missoula, Montana, joined the Intermountain Station staff in 1961. He holds the B.S. and M.S. degrees in forest management from Iowa State University and Oregon State University, respectively, and recently received a Ph. D. degree in botany from Washington State University. During part of this study the author was stationed at the Forestry Sciences Laboratory in Moscow, Idaho.

Tr. to or frort cover shows rrowth of a western white pine tree in a cleared plot \& years after treatment; on back cover, same tree is shown 14 years xfter treatment (left) and 37 years after treatment (right). 


\title{
GROWTH OF RELEASED AND UNRELEASED YOUNG STANDS IN THE WESTERN WHITE PINE TYPE
}

\author{
Glenn H. Deitschman and Robert D. Pfister
}

INTERMOUNTAIN FOREST AND RANGE EXPERIMENT STATION

Forest Service

U.S. Department of Agriculture

Ogden, Utah 84401

Robert W. Harris, Director 


\section{CONTENTS}

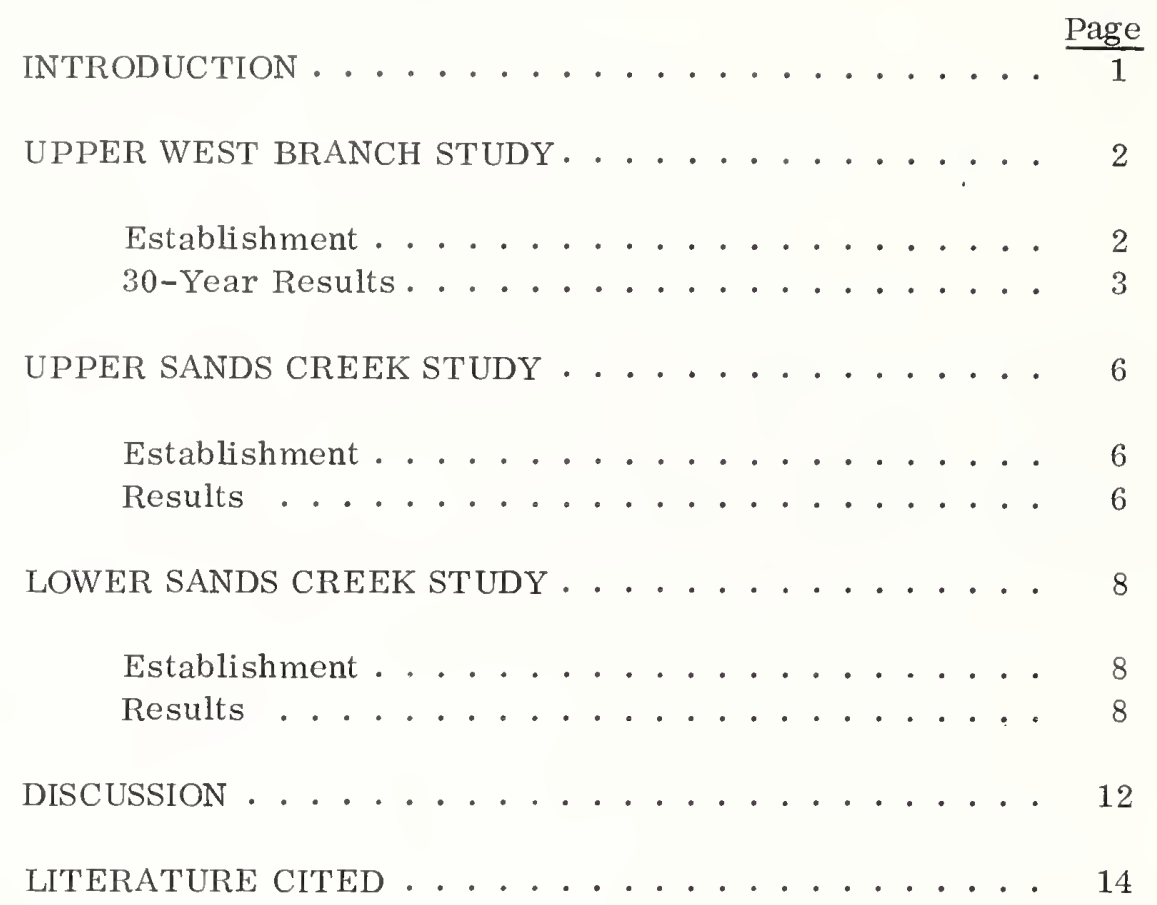

\section{ABSSTRAC'T}

Effects of release by removal of a residual overstory and by cleaning treatments were measured over a 30-year period in young mixed-conifer stands on moist sites in northern Idaho. Increasing time of overwood retention caused rapid loss of the more intolerant species and corresponding reduction in subsequent alternatives for crop-tree selections. Cleaning effectively promoted the growth of leave trees (principally western white pine), but the amount and duration of benefit was decreased by an aggressive reappearance of tolerant and intolerant species, especially in heavily cleaned plots. 


\section{INTRODUCTION}

Three separate but related studies established in northern Idaho in $1935^{1}$ provide information on the response of representative young stands to release from overstory shade and to lower densities achieved by cleaning. The parent timber type in each case was western white pine (Pinus monticola Doug1.); ecologically, the sites were classified as Tsuga heterophyzZa/Pachistima myrsinites habitat type (Daubenmire and Daubenmire 1968). Some early results of cleaning operations on two of the study areas were described by Wellner $(1940,1946)$. Boyd (1959) later reported on conditions and outlook on these same areas 20 years after treatments. Ten more years of record, plus results from a third set of plots, now give additional data on growth and dominance trends.

The treatments used were designed to favor western white pine because of its paramount importance to the timber industries at that time. Current management programs in the Northern Rocky Mountain region have deemphasized white pine production because of the problems encountered in attempting to control losses from blister rust (Ketcham and others 1968). Although the prospective role of natural white pine in this region remains uncertain, progress toward producing genetically rust-resistant trees for planting indicates there will be a continuing use for information on the responses of western white pine to management practices. In addition, the records from these early studies can help managers formulate guidelines for mixed-species management on similar sites.

${ }^{1}$ These studies were planned and installed by Carl E. Ostrom, Hans Roffler, George M. Fisher, and Kenneth P. Davis; data on file at Intermountain Forest and Range Exp. Station, Forestry Sciences Laboratory, Moscow, Idaho. 


\section{UPPER WEST BRANCH STUDY}

\section{Establishment}

This set of cleaning plots was established in an 8-year-old stand occupying a level bench in the Upper West Branch drainage of Priest River in the Kaniksu National Forest. The stand originated after a 1926 burn of logged-over old growth. In 1935, densi.ty per acre ranged from 9,000 to 21,000 trees that were over 0.5 foot in height. Of these, moxe than half were seedlings in the 0.5 - to 1.5 -foot range, chiefly western hemlock (Tsuga heterophyzza (Raf.) Sarg.) and western redcedar (Thuja plicata Donn). Western larch (Larix occidentalis Nutt.) was strongly dominant over the entire area, with only scattered lodgepole pine (Pinus contorta Dougl.) and western white pine appearing among the taller trees in the stand.

The study installation consisted of three 0.4 -acre plots treated as follows:

Uncleaned.--This was the check plot.

Moderately cleaned.--All white pine and redcedar were left, together with a few Engelmann spruce (Picea engelmannii Parry) and Douglas-fir (Pseudotsuga menziesii (Mirb.) that were not crowding the white pine. Also, where white pine was absent, small larches were left and given an 8-foot spacing. redcedar.

Heavity cleaned.--All trees taller than 0.5 foot were cut, except white pine and

As a result of the moderate cleaning, the density was lowered to about 2,700 stems per acre, and the percentage of 4-milacre quadrats dominated by white pine increased from 1 percent before treatment to 45 percent after. Most of the remaining quadrats continued to be dominated by western larch. Heavy cleaning lowered the average density to 1,760 trees per acre. The percentage of quadrats with dominant white pine was raised to 70 percent, and redcedar temporarily became the tallest species on the rest of the quadrats. 


\section{0-Year Results}

By 1965, 30 years after treatment, western larch in the moderately cleaned plot had increased its percentage of the trees in the dominant and codominant crown classes from about 50 to nearly 75 percent--thereby regaining much of its pretreatment advantage over western white pine (fig. 1). In the heavily cleaned plot, where virtually all larch except very small seedlings had been removed, this species made a surprising comeback and accounted for more than 40 percent of the trees in dominant and codominant crown classes by the time of the 1965 measurement. Reestablishment of lodgepole pine on these cleaned plots was almost nil. Western hemlock and western redcedar made a strong recovery in the understory, especially where the heavy cleaning was done; after only 15 years, these two species totaled more than 7,000 stems there. In the check plot, western larch and lodgepole pine continued to exert complete dominance, and by 1965 the western white pine population had been reduced to scattered, suppressed, and declining individuals.

Posttreatment growth rate of the trees has shown a direct relationship to the intensity of western white pine release. In comparison with the check plot, the acceleration of diameter increment on released trees resulted in total basal areas that were 20 percent higher in the moderately cleaned plot and 40 percent higher in the heavily cleaned plot (fig. 2). Also, height growth of the larger trees was similarly improved (fig. 3). Based on measurements of the tallest too trees per acre of each species, white pine at 38 years attained a height of only 13 feet on the check plot compared to 46 feet under the moderately cleaned conditions and 54 feet where heavily cleaned.

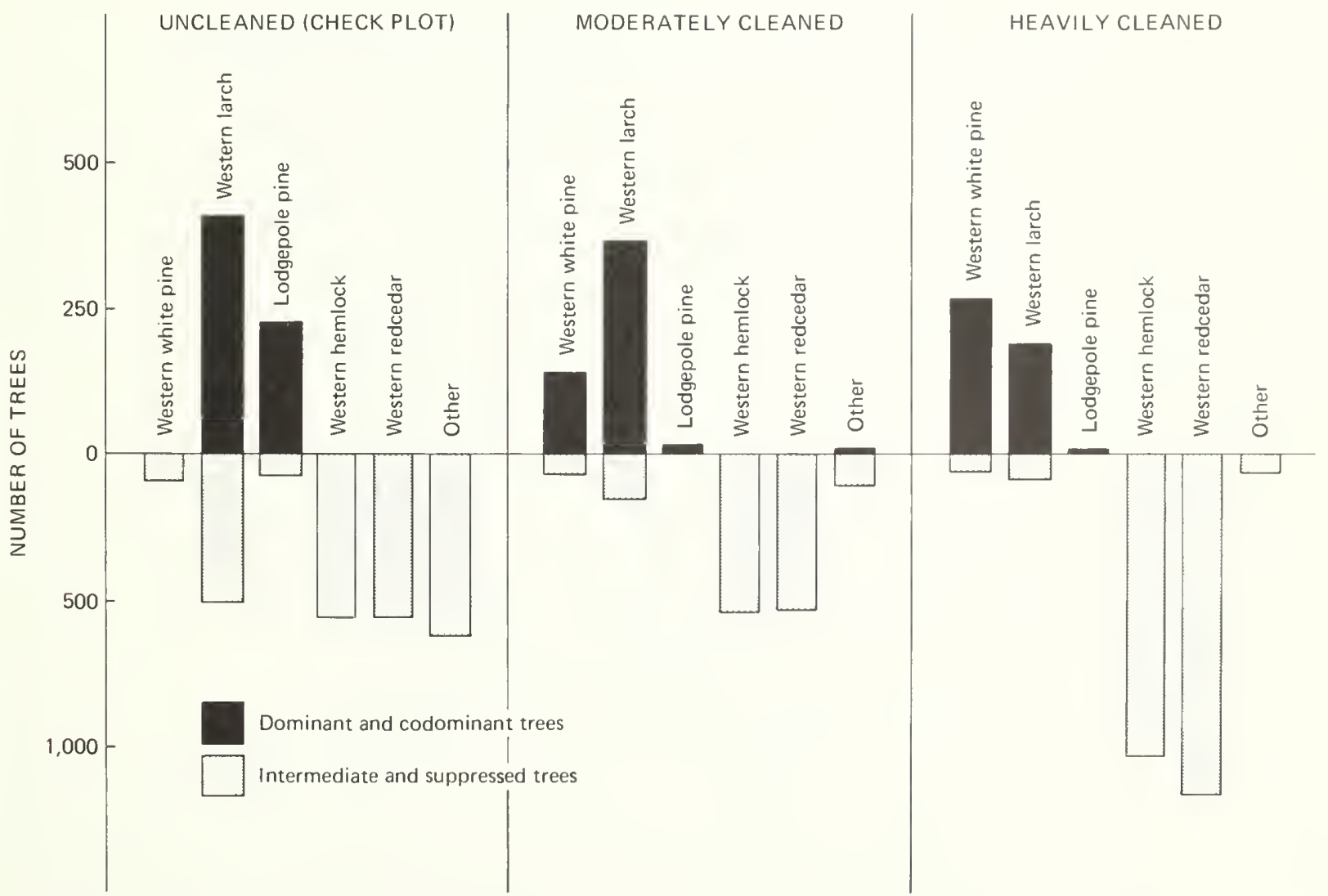

Figure 1.--Effect of moderate and heavy cleanings on number of trees per acre 30 years after treatment, by crown class and species, Upper West Branch study. 
Western larch was also benefited by the cleanings although all of the largest trees of this species had been cut; of those remaining, the taller ones outgrew the dominant larch on the check plot by about a third during the 30 years after treatment. The height growth of lodgepole pine closely matched that of western larch in the check plot, but too few of the lodgepole pine reappeared in the other plots after cleaning for valid height comparisons.

Although the rates of western redcedar height growth were comparatively slow on all plots, it is noteworthy that the redcedar grew about twice as fast in the heavily cleaned plot after treatment as it did in the check plot. The results for western hemlock were nearly identical to those for redcedar, even in the cleaned plots where the hemlock had been strongly discriminated against. Heights of the two species, therefore, were combined for the treatment comparisons in figure 3.

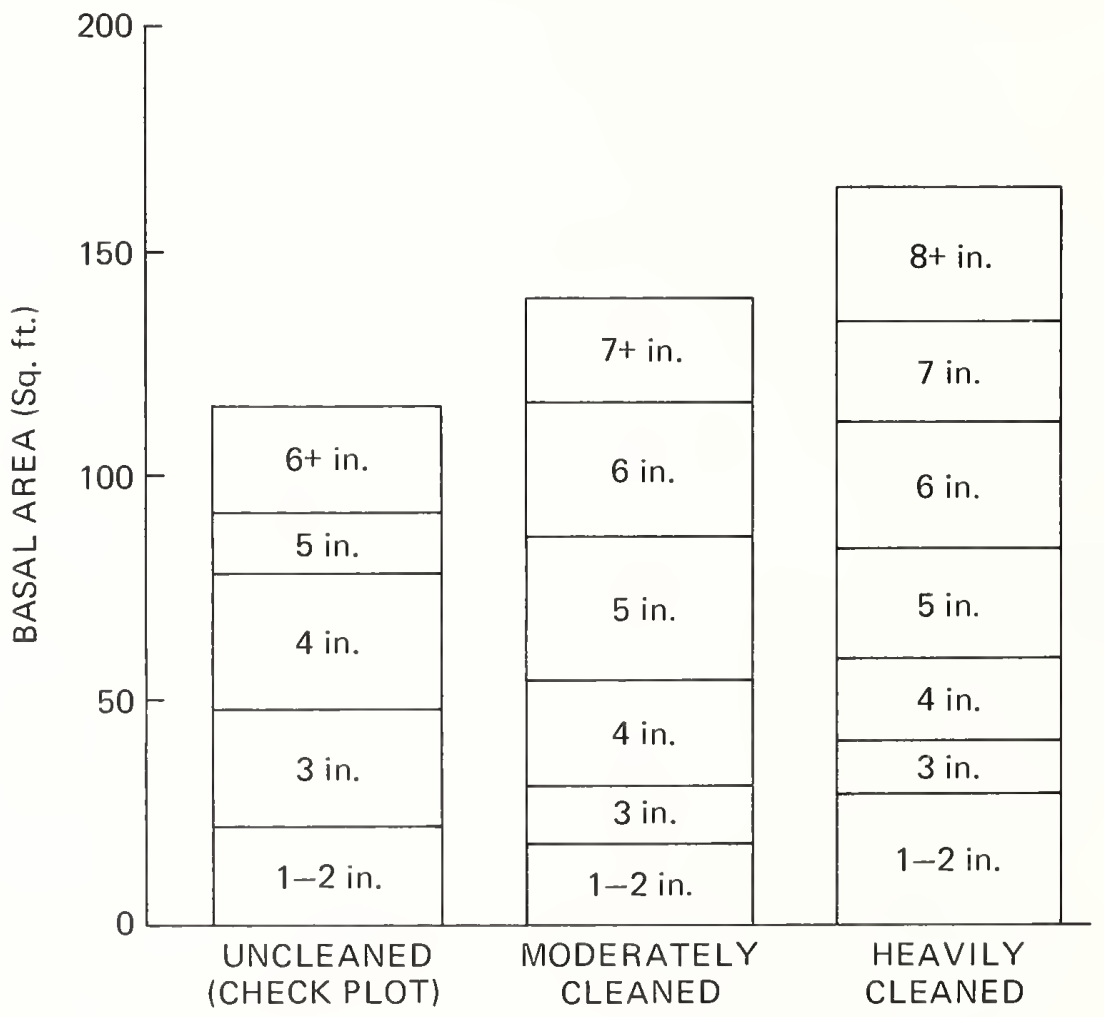

Figure 2.--Effect of moderate and heavy cleanings on total basal area per acre 30 years after treatment by 1-inch d.b.h. classes, Upper West Branch study. 

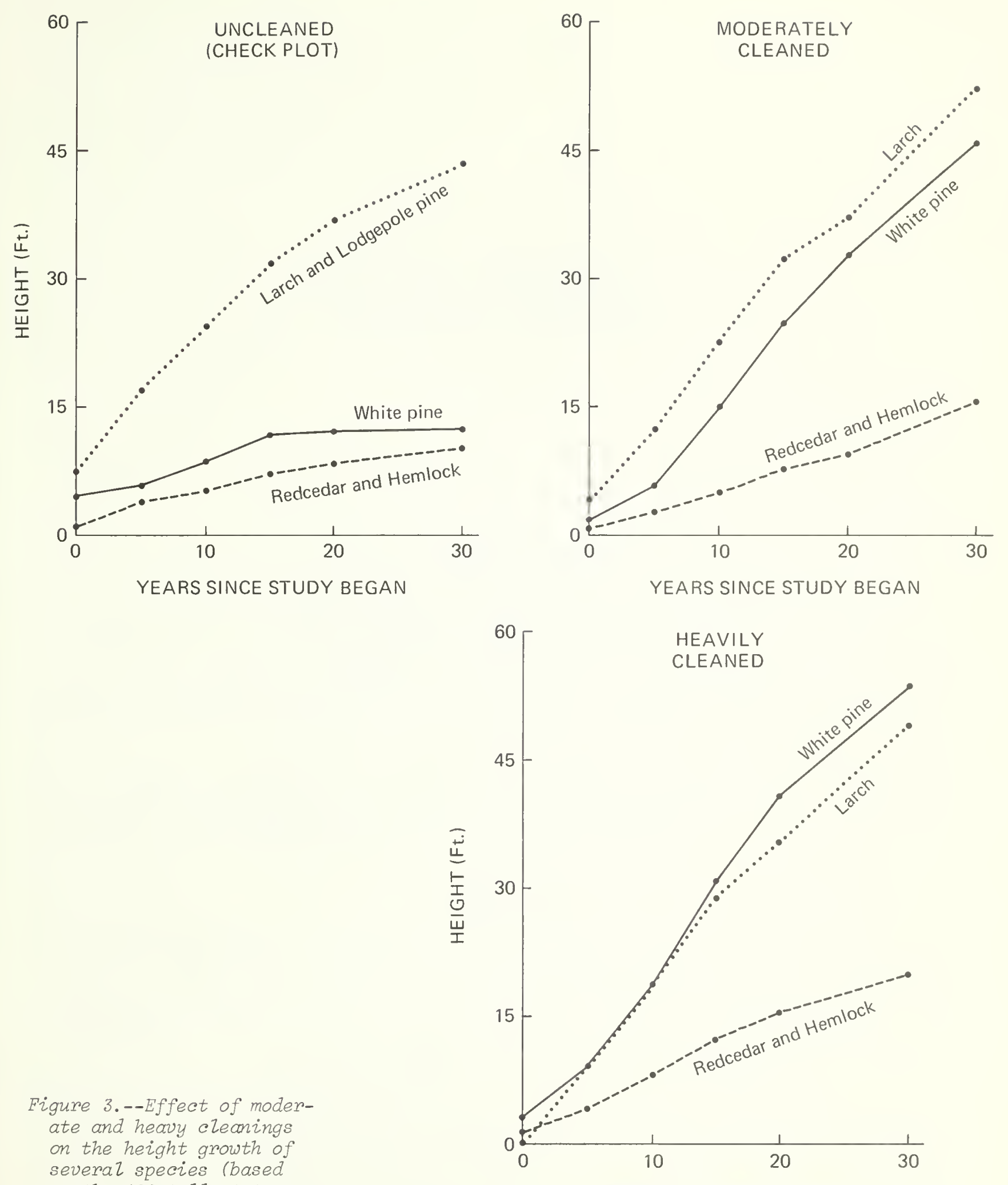

igure 3.--Effect of moderate and heavy cleanings on the height growth of several species (based on the 100 tallest trees per acre of each species), YEARS SINCE STUDY BEGAN Upper West Bronch study. 


\section{UPPER SANDS CREEK STUDY}

\section{Establishment}

This study was located in the Sands Creek drainage of the Deception Creek Experimental Forest at an elevation averaging about 3,500 feet on middle-to-lower northerly slopes. It was established in a 16-year-old stand composed mainly of grand fir (Abies grandis (Doug1.) Lind1.), western hemlock, and western white pine. White pine seed trees that had been left after logging in 1916-1918 were removed in 1935 when the cleaning treatments were applied. The study installations consist of three blocks of three 1/10-acre plots, two cleaned and one uncleaned in each block.

Cleaning reduced average density of all the trees over 0.5 foot in height from nearly 7,000 per acre to about 1,600 per acre. The average percentage of highly favored western white pine was raised from 21 to 81 percent. Western redcedar was 1 eft where it occurred, but not many trees of this species were present in this study area.

\section{Results}

In the check plots, western white pine, hemlock, and grand fir grew at nearly the same rates for the first 20 years after study establishment. Thereafter, grand fir outgrew the white pine and western hemlock by about 0.6 foot per year (fig. 4). White pine's drop in performance was partly attributable to blister-rust infection and loss of several of the larger trees. As a result, nearly two-thirds of the codominant and dominant stand consisted of grand fir by the end of the period of study. The western redcedar remained severely suppressed and few reached sapling size.

The high percentage of favored western white pine that had been left in the cleaned plots was quickly lowered by the aggressive regrowth of grand fir and western hemlock. Although the white pine grew rapidly and maintained nearly complete dominance (fig. 4), by 30 years after the cleaning the other two major species had regained sufficient representation to constitute about two-thirds of all the trees and one-third of the total basal area. Again, in spite of the preferential treatment it received, the typically slow-growing redcedar was soon overtopped. 

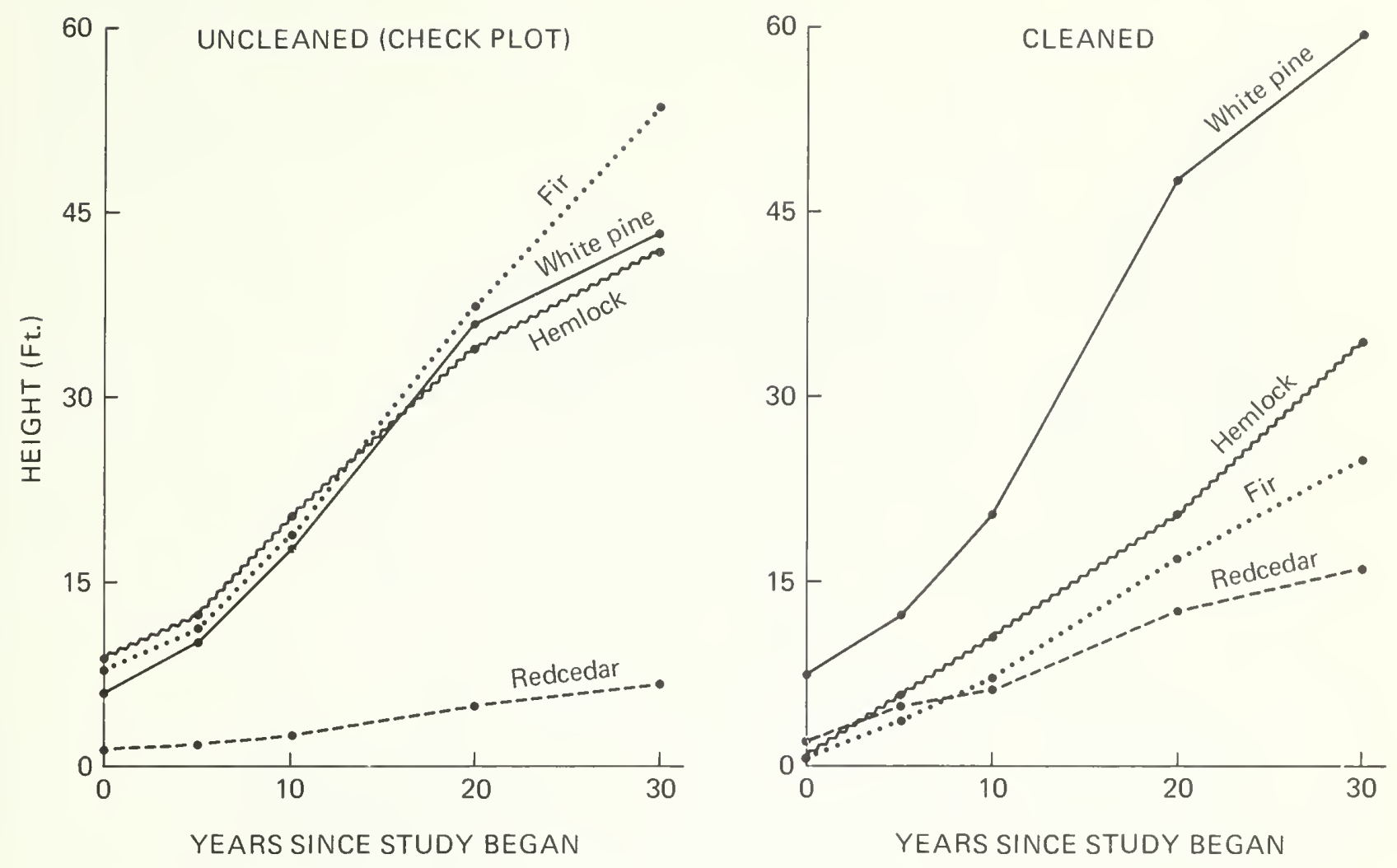

Figure 4.--Effect of cleaning on the height growth of westem white pine, western hemlock, and grand fir (based on the 100 tallest trees per acre of each species), Upper Sands Creek study. 


\section{LOWER SANDS CREEK STUDY}

\section{Establishment}

This study was also located in the Sands Creek drainage, but on the lower part of the northerly slope. The area was logged-over for western white pine about 1916, leaving a residual stand of defective grand fir and western hemlock. As a result of the logging disturbance, more than 18,000 seedlings per acre, many of them white pine, became established. During the following 18 years, expanding crowns of the residual overstory trees reduced the average amount of light available to the seedlings to about 25 percent of full sunlight. Western white pine still persisted, but the species was becoming increasingly overtopped by the more shade-tolerant grand fir and hemlock.

In 1935, two silvicultural measures were employed on half of the area to release the white pine and western redcedar regeneration which then averaged about 15 years old. First, the overstory was removed by girdling the trees over 20 inches in diameter and felling the smaller ones. Secondly, competing grand fir and hemlock seedlings were removed by a cleaning operation. This reduced the number of seedlings by 80 percent to about 3,500 per acre. Neither overstory removal nor cleaning was done on the remaining half of the area.

Two 0.1-acre sample plots were installed in each half in 1935, and these were remeasured in $1940,1945,1950,1955$, and 1965. Tree counts and height measurements were made each time. Beginning in 1945, stocking information by 1 - and 4-milacre quadrats was also obtained.

\section{Results}

Under the heavily-shaded conditions of the unreleased check plots, western white pine was nearly eliminated from the reproduction stand by suppression during the 30-year period of observation (fig. 5). Even grand fir suffered considerable attrition, dropping from 25 percent of the stand at the beginning of the study to less than 10 percent at the end. Western hemlock, on the other hand, continued to increase both in numbers and size. Measurements taken on 4-milacre sample quadrats revealed that over three-fourths of the quadrats were dominated by hemlock at the last examination. 


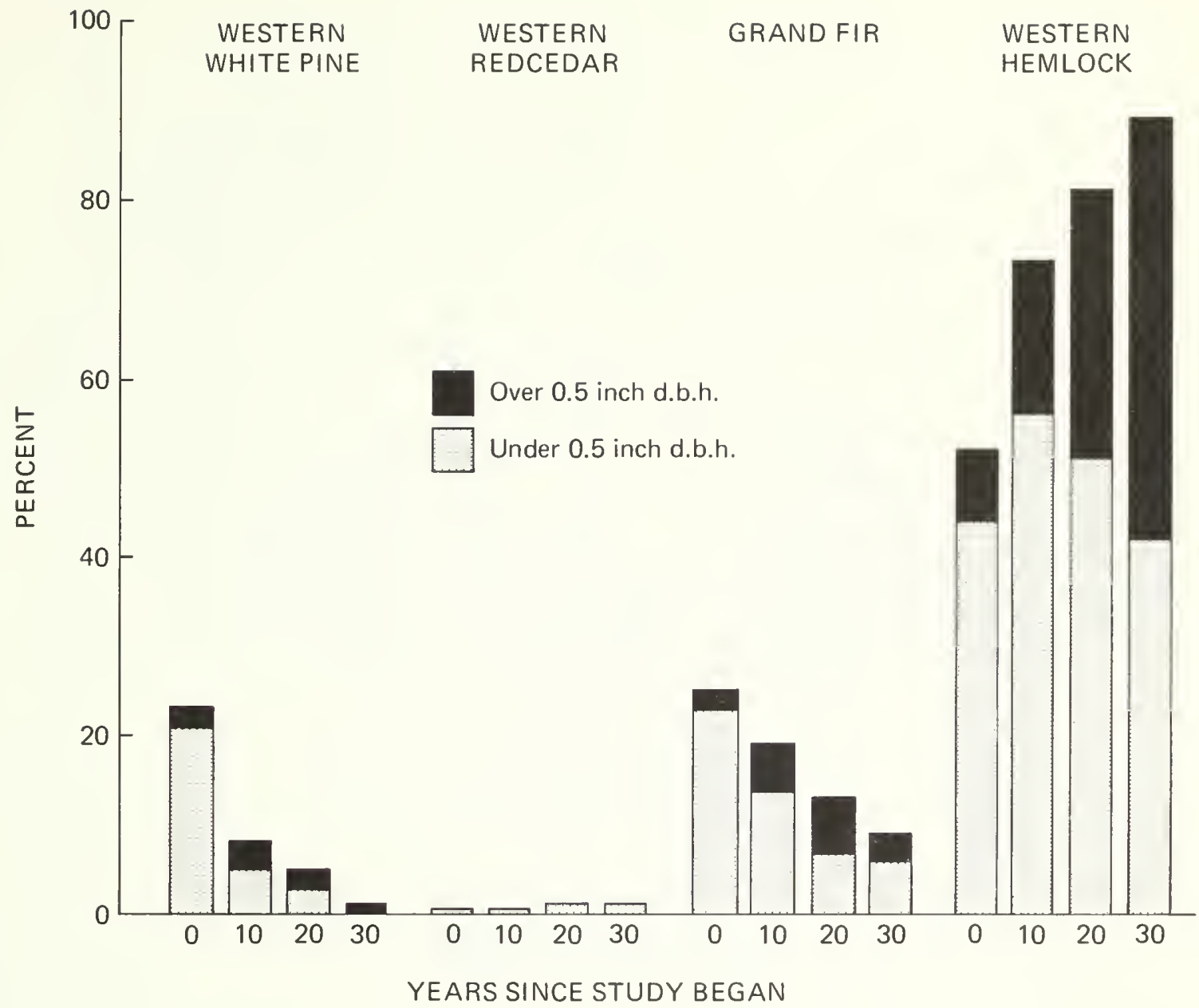

Figure 5.--Percentages of all trees in the check plots that were more than or less than 0.5 inch d.b.h. at 10-year intervals, by species, Lower Sands Creek study.

Western redcedar was poorly represented on these plots initially, and remained so. For the first 10 years after measurements were begun, sufficient light was transmitted through the overstory trees to permit moderate growth of the young trees. Thereafter, increasing shade reduced the height increment of all species to insignificant amounts (fig. 6).

On the area that received release and cleaning treatments, the numbers of western white pine and western redcedar that had been left remained about the same for the first 10 years, but western hemlock and grand fir again showed up in striking numbers (fig. 7). It is probable that much of this apparent reinvasion resulted from seedlings that had been ignored during the cleaning operation. By the end of the 30-year period of study, western hemlock and grand fir comprised 2,000 of the 2,900 trees per acre then present, although few reached a position of dominance.

Based on heights of the best trees of each species, western white pine responded very well to the preferential cleaning treatment and grew more than twice as fast as its associates (fig. 6). Western redcedar was unable to exploit its initial advantage, barely managing to keep pace with grand fir and western hemlock. 

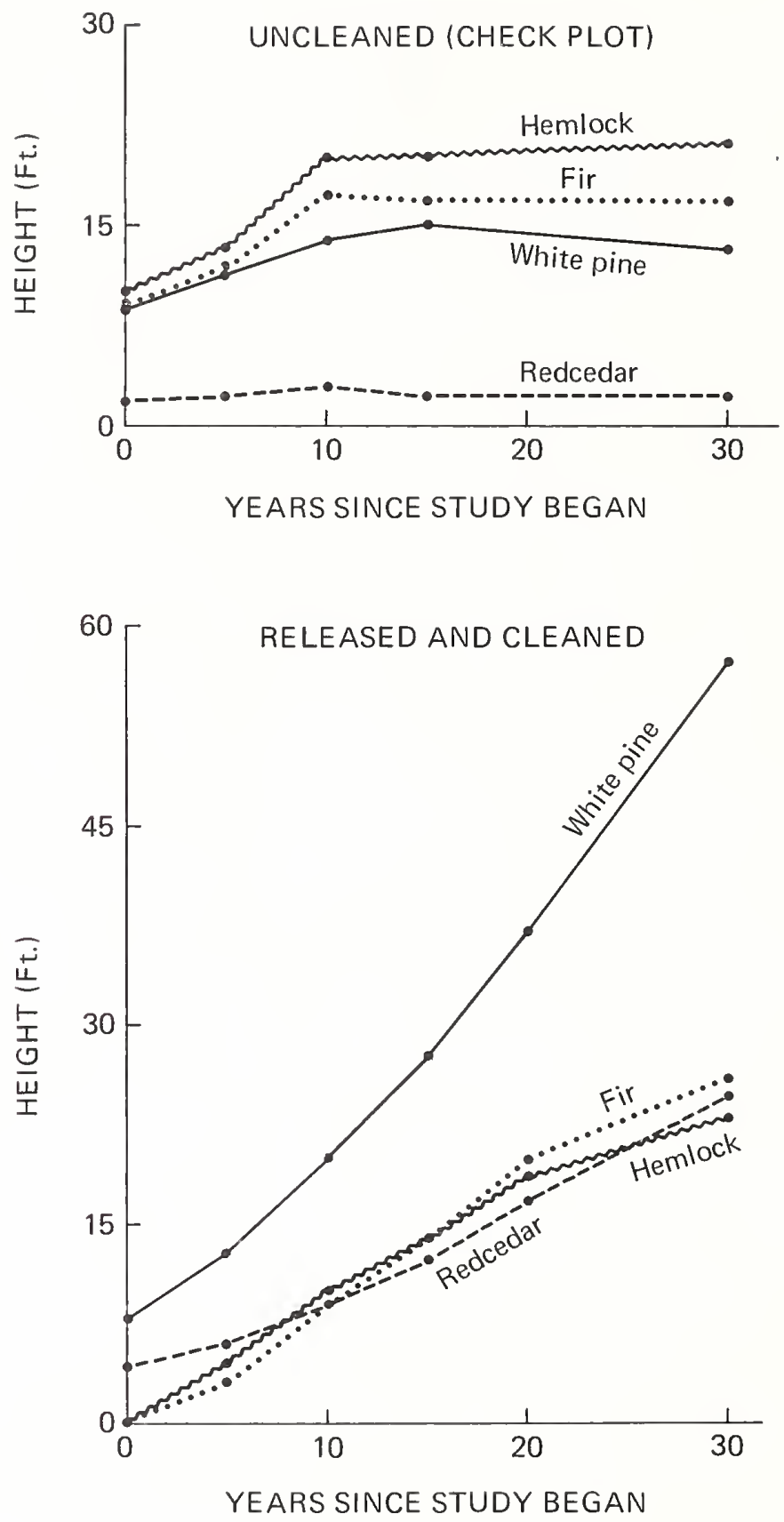

Figure 6.--Effect of cleaning on the height growth of westerm white pine, grand fir, westerm redcedar, and westem hemlock (based on the 100 tallest trees per acre of each species), Lower Sands Creek study. 


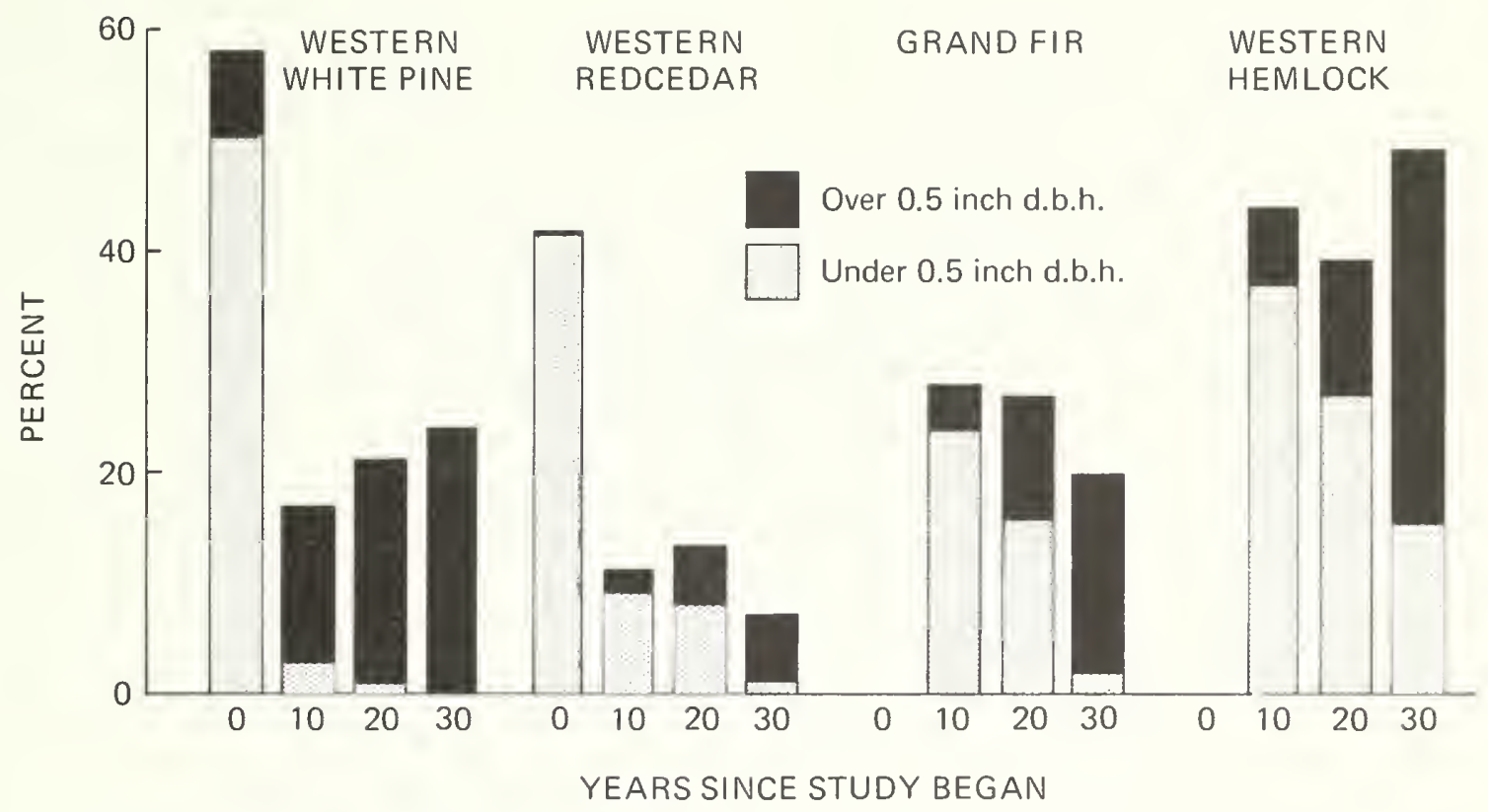

Figure 7.--Percentage of all trees in the released and cleaned plots that were more than or less than 0.5 inch d.b.h., at 10-year intervals, by species, Lower Sands creek Study. 


\section{DISCUSSION}

The Tsuga/Pachistima habitat type, within which each of the three study areas occurred, is one of the most productive habitat types of the Northern Rocky Mountains. It is also characterized by a broad representation of tree species. Where advance seedlings or seed are present after timber harvests, or seed sources remain within range, natural regeneration is customarily prompt and soon results in heavily overstocked young stands that may contain as many as seven or eight commercially important coniferous species in significant numbers.

In areas where reproduction has become established under partial cuttings, the density of the residual overstory and the time until it is removed greatly affect reproduction development. The growth of intolerant species such as western $1 \mathrm{arch}$, Douglas-fir, and western white pine is soon inhibited by as little shading as that cast by a light shelterwood. Under heavily shaded conditions such as those in the check plot area of the Lower Sands Creek study, suppression mortality rapidly reduces the number of intolerant trees. Even the quite tolerant grand fir suffers severe attrition, eventually reducing the diversity of tree species available for later selection of management alternatives simply to western hemlock and, perhaps, western redcedar. It is likely, also, that the high incidence of heartrot usually found in older stands of these tolerant species may be associated with greater susceptibility to injury and infection during the long period typically spent as very slow-growing subordinate trees.

Where reproduction stands have developed in clearcuts or where they have been given early release from partially cut overstories, cleaning operations made while the stands are still less than 30 to 35 years of age offer the best opportunity for selecting desirable combinations and distributions of species. Postponing the reduction in density to later years may again sacrifice much in the diversity of species that might be featured in management. This was true in the Upper West Branch study check plots where western larch and lodgepole pine strongly dominated the stand at 38 years of age. Any attempt then to favor other species by precommercial thinnings would pose problems of adequacy of release; and heavy cutting of the larch and lodgepole pine would mean the loss of considerable past stand production that had been concentrated on those larger trees. In addition, some species, such as western white pine, lose their ability to respond quickly and vigorously when release from heavy competition is delayed much beyond 30 years (Deitschman 1966). 
Early cleanings, on the other hand, are effective in molding species' composition only to the extent that the favored individuals are able to retain their advantage. If faster growing species reenter quickly (or are present as "missed" seedlings), they may overtake the leave stand before crowns of the latter close sufficiently to suppress the threat. This hazard becomes relatively greater under the following conditions: (1) The younger the cleaned stand, the less is the size and age disadvantage of potential new competitors; (2) the heavier the cleaning treatment, the longer is the time before crowns of the intended leave stand can cast effective shade; and (3) the greater the disparity in growth rates between slow-growing leave trees and fast-growing invaders, the shorter is the duration of cleaning effectiveness. As illustration of the third point, the performance of released white pine on the study plots was strongly benefited, but the limited response of released western redcedar hardly enabled it to keep up with the other species that reappeared in the understory.

Of the species on the study areas that were discriminated against during cleaning, western larch has most aggressively regained a dominant or codominant role. Conversely, lodgepole pine, once removed, does not appear able to make a significant reappearance. Grand fir became numerically important again in the Sands Creek study areas in the years after cleaning, but it was unable to escape the growth-retarding shade of taller associates. This species is one of the most responsive to release from competition, so had it been given any preferential treatment, its growth rate on these sites would probabiy have about equaled that of the western white pine.

Western hemlock has shown remarkable ability to recover promptly and strongly in the stands from which it ostensibly was removed by cleaning. While these trees generally remain in an understory position, their density and volume indicate an appreciable diversion of the production capacity of the site away from the selected potential crop trees.

Since these studies were started, western white pine blister rust and the larch casebearer have altered normal development, growth, and management potential of most natural stands in the Tsuga/Pachistima habitat type (Ketcham and others 1968; Tunnock and others 1969). Nevertheless, the study results and conclusions are applicable in principle to other young stands growing under similar conditions. The mixed composition of natural reproduction typical of this habitat type provides ample opportunity to leave well-distributed trees of several species in the cleaned stand; this opportunity was not fully utilized in the described studies. If this were done, there would be greater flexibility at the time of future thinnings for further preferential decisions about species to be left. 


\section{LITERATURE CITED}

Boyd, Raymond J.

1959. Cleaning to favor western white pine--its effects upon composition, growth, and potential values. J. For. 57(5):333-336.

Daubenmire, R., and Jean B. Daubenmire.

1968. Forest vegetation of eastern Washington and northern Idaho. Wash. Agric. Exp. Sta. Tech. Bu11. 60, 104 p.

Deitschman, Glenn H.

1966. Diameter growth of western white pine following precommercial thinning. USDA For. Serv. Res. Note INT-47, 4 p.

Ketcham, David E., Charles A. Wellner, and Samuel S. Evans, Jr.

1968. Western white pine management programs realigned on northern Rocky Mountain forests. J. For. 66:329-332.

Tunnock, Scott, Robert E. Denton, Clinton E. Carlson, and Willis W. Janssen

1969. Larch casebearer and other factors involved with deterioration of western larch stands in northern Idaho. USDA For. Serv. Res. Pap. INT-68, 10 p.

We1lner, C. A.

1940. Effects of cleaning in a reproduction stand of western white pine and associates. USDA For. Serv., North. Rocky Mt. For. and Range Exp. Sta. Res. Note $4,4 \mathrm{p}$.

We1lner, C. A.

1946. Improving composition in young western white pine stands. USDA For. Serv. North. Rocky Mt. For. and Range Exp. Sta. Res. Note 43, 6 p. 

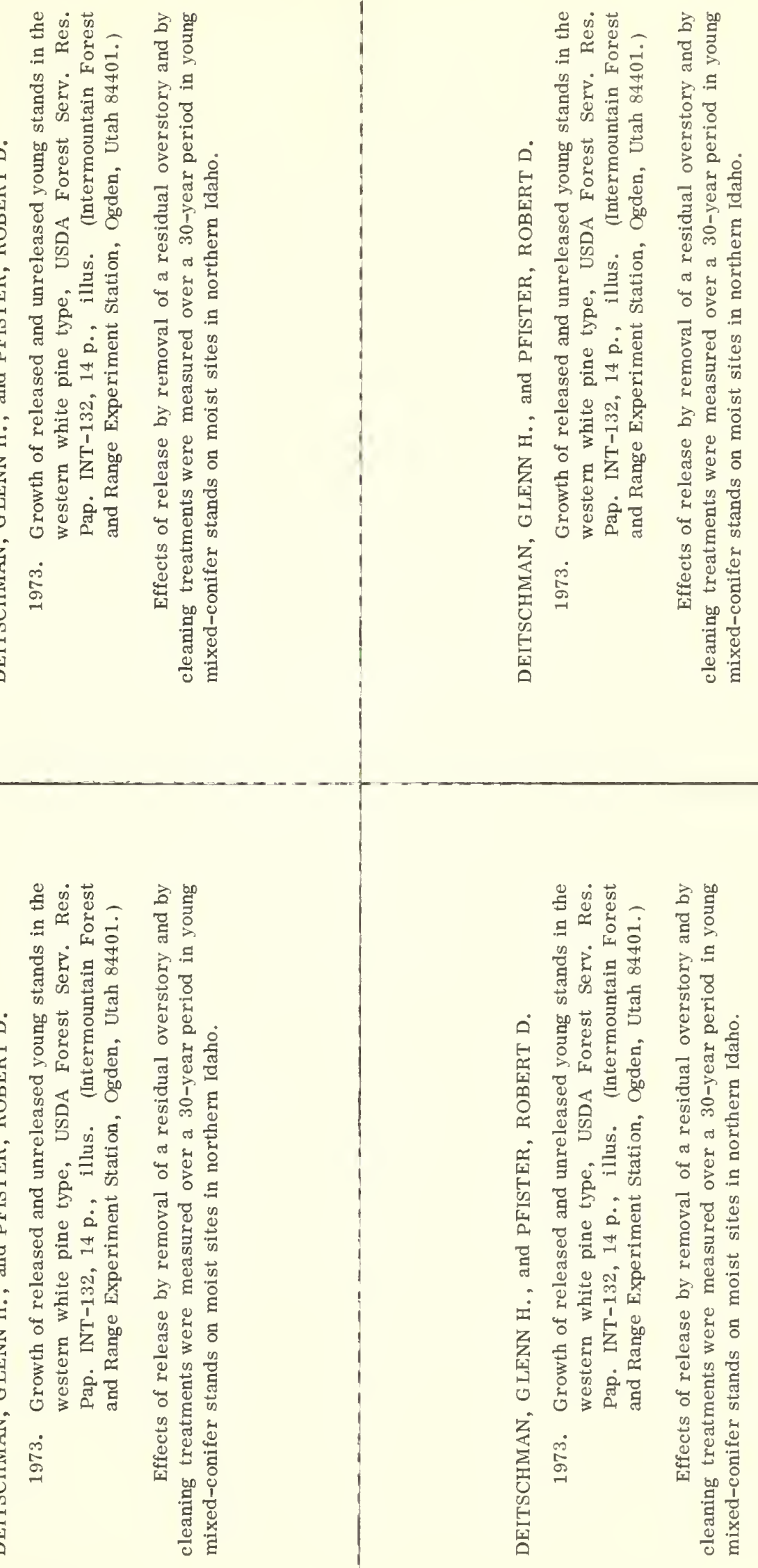

Headquarters for the Intermountain Forest and Range Experiment Station are in Ogden, Ltah. Field Research Work Inits are maintained in:

Boise, Idaho

Bozeman, Montana (in cooperation with Montana State University)

Logan, Utah (in cooperation with Ltah State (niversity)

Missoula, Montana (in cooperation with University of Montana)

Moscow, Idaho (in cooperation with the I niversity of Iciaho)

Provo, Utah(in cooperation with Brigham Young University)

IReno, Nevada (in cooperation with (niversity of Nevada) 
